\title{
INFORMAÇÃO PARA O CONHECIMENTO
}

No n.2 de 2020, nosso Editorial abordou A Ciência em ação, sobre o momento histórico que ainda estamos vivendo sob o jugo da pandemia do Covid-19. Dizíamos que, em todo o mundo, instituições de pesquisa publicavam editais "conclamando cientistas a se reunirem para encontrar respostas em nível de antecipação (vacina) ou terapia" (FREIRE; FREIRE, 2020).

Os cientistas atenderam ao chamado, e contradizendo a Organização Mundial da Saúde, que publicou, no final de fevereiro de 2020, um comunicado afirmando não esperar uma vacina em menos de 18 meses, em dezembro do mesmo ano cerca de 59 vacinas estavam em investigação clínica, 42 em testes de Fase I-II, e 17 em testes de Fase II-III. ${ }^{1}$ E ainda em dezembro, oito vacinas foram liberadas e logo estavam sendo usadas, de forma emergencial em 50 países: Sputnik V, Sinopharm-Pequim, Moderna, Vector, CoronaVac, Pfizer-BioNTech, Cansino e Oxford-AstraZeneca. Em 29 de janeiro de 2021, levantamento do G1, o Portal de Notícias da Globo, informava que havia 236 vacinas em teste no mundo². Trata-se do maior esforço científico já desenvolvido, em busca de respostas para uma pandemia que ameaça a própria sobrevivência da espécie humana.

A produção de informação sobre Covid-19 também acompanhou esse esforço científico, seja na mídia jornalística, onde os principais jornais e revistas de circulação nacional reservaram espaço em editoriais e pautas de redação, seja nas bases de dados científicas, onde os resultados de pesquisas são compartilhados.

Uma busca no Portal de Períodos da Capes, que disponibiliza conta, atualmente, um acervo de mais de 45 mil periódicos com texto completo e 130 bases referenciais, entre outras fontes, identificou, no período de 2020-2021, 163.736 artigos de periódicos sobre 0 assunto, além de 87.184 artigos de jornais, 1.766 resenhas 853 arquivos com recursos textuais e 37 livros. No Portal, o tópico Covid-19 aparece 117.940 vezes e o tópico Coronavírus aparece 48.135 vezes. $^{3}$

Na Biblioteca Virtual em Saúde (BVS), "uma Rede de Redes construída coletivamente e coordenada pela BIREME" (BVS, 2021)4', uma busca por assunto Covid-19 identificou 107.059 referências, a maioria sobre infecções por coronavírus (45.149 referências), bem como sobre pneumonia viral, pandemias,

1 Fonte: https://pt.wikipedia.org/wiki/Vacina_contra_a_COVID-19. Acesso em 16 mar. 2021.

2 Fonte: https://g1.globo.com/bemestar/vacina/noticia/2021/01/29/mundo-pesquisa-236-vacinas-e-ja-testa-16-em-humanos-mas-poucas-tem-chance-de-chegar-ao-brasil-avaliam-especialistas.ghtml. Acesso em 22 mar. 2021.

3 Fonte: https://www-periodicos-capes-gov-br.ezl.periodicos.capes.gov.br/. Acesso em 16 mar. 2021.

4 Fonte: https://bvsalud.org/. Acesso em 16 mar. 2021. 
betacoronavírus, antivirais, controle de doenças transmissíveis e quarentena, entre outros. Na base de dados Saúde Brasil, disponibilizada na BVS, uma busca nos campos de título, resumo e assunto identificou 131.748 referências, sendo 111.387 com texto completo. ${ }^{5}$

Destarte, uma busca nos campos título, palavras-chave, resumo e texto completo, no período de 2019-2021, na Base de Dados da Ciência da Informação (Brapci), que disponibiliza referências e resumos de 19.255 textos publicados em 57 periódicos nacionais impressos e eletrônicos, recuperou nos campos título, palavras-chave, resumo e texto completo, no período 2019-2021, recuperou 169 referências, a saber: 14 referências em 2019; 143 referências em 2020; e 12 referências em $2021 .{ }^{6}$

Instituições de pesquisa na área da saúde, como o Instituto Butantan, que produz a vacina CoronaVac no Brasil, e a Fiocruz, que produz a vacina Oxford-AstraZeneca brasileira, oferecem, em seus sites na Internet, janela para acesso a informações sobre Covid-19, como notas técnicas, vídeos, artigos científicos, links para mapas situacionais, entre muitas outras informações sobre a pandemia.

E o Instituto Brasileiro de Informação em Ciência e Tecnologia (IBICT) disponibiliza, em seu site, um Especial Coronavírus - Mapa interativo com informações oficiais relacionadas ao Covid-19, constando de indicadores sobre casos de Covid-19 e óbitos informados pelas Secretarias de Saúde dos Estados, com dados sobre população por faixa etária; informações epidemiológicas e de morbidade; informações sobre trabalho e renda, leitos e insumos e profissionais da saúde. Os dados podem ser filtrados por Região do Brasil, casos (confirmados, óbitos, recuperados) e tipo de transmissão.

Sabemos que o conhecimento voa nas asas da informação, e "A informação sintoniza o mundo. Como onda ou partícula, participa na evolução e da revolução do homem em direção à sua história" (BARRET0, 1994, p. 3). Esperamos que a força da informação nos mova não somente na direção de uma vacina ou da cura para infecções por Covid-19, mas, principalmente, acorde a consciência para a busca de uma humanidade mais lúcida, fraterna e dona do próprio destino. Com a inestimável ajuda da pesquisa e da informação científica.

Gustavo Henrique de Araújo Freire

Isa Maria Freire

Editores

$5 \quad$ Fonte: http://saudepublica.bvs.br/. Acesso em 16 mar. 2021.

6 Fonte: https://brapci.inf.br/. Pesquisa em 16 mar. 2021. 